\title{
カテーテル関連血流感染予防に向けた皮膚消毒薬としての
}

\section{$1 \mathrm{w} / \mathrm{v} \%$ クロルヘキシジン $(\mathbf{C H G})$ エタノールの有効性と安全性}

\author{
西原 豊 1,2$) \cdot$ 梶浦 $\quad$ 工 $^{1,2)} \cdot$ 横田 勝弘 ${ }^{1}$ \\ 小林＼cjkstart寬伊 ${ }^{2}$ ·菅原えりさ2）大久保 憲 ${ }^{2}$
}

\section{Use of $1 w / v \%$ Chlorhexidine Gluconate in Alcohol Formulation for Reducing The Risk of Catheter-Related Bloodstream Infection}

\author{
Yutaka NishinarA ${ }^{1,2)}$, Takumi KaJiURA ${ }^{1,2)}$, Katsuhiro YoKota ${ }^{11}$, \\ Hiroyoshi KobaYashi ${ }^{2)}$, Erisa Sugawara ${ }^{2)}$ and Takashi OKUBO ${ }^{2}$ \\ 1) Yoshida Pharmaceutical Co., Ltd., Microbiological Research Dept., Research \& Development Div. \\ 2) Tokyo Healthcare University Postgraduate School \\ $(2012$ 年 12 月 26 日 受付 $\cdot 2013$ 年 1 月 28 日 受理)
}

\section{要旨}

日本国内では, 血管内留置カテーテル挿入部位の皮膚消毒薬として, $10 \%$ ポビドンヨード液 (10\%PVP-I)が広く使用されてきた. しかし，米国 CDC が「血管内留置カテーテル関連感染予防 のためのガイドライン 2011」を公表し「中心静脈カテーテルや末梢動脈カテーテル挿入前抢よび ドレッシング交換時にはクロルヘキシジン $(\mathrm{CHG})$ 濃度が $0.5 \%$ を超える $(>0.5 \%)$ アルコール製剂 で皮膚消毒すること」を推奨して以降，特に米国では PVP-I から主に $2 \% \mathrm{CHG}$ 含有のアルコール 製剂への置き換えが進んでいる. わが国に扔いては, 中心静脈カテーテル関連血流感染 (CLABSI) を含むカテーテル関連血流感染 (CRBSI) 予防のための皮膚消毒薬として, CDC ガイドラインの要 件を満たし且つ薬事上適用可能な $1 \mathrm{w} / \mathrm{v} \% \mathrm{CHG}$ 含有エタノール製剤 (1\% CHG-EtOH) が医療現場 で採用される傾向にある。これら状況を踏まえ， $1 \% \mathrm{CHG}-\mathrm{EtOH} の$ の特徵を調べた結果, 薬効(消毒 7 日後の持続効果), 実使用上に抢ける安全性 (皮膚に低刺激)などの科学的データ，ならびに国内 での臨床的エビデンス(CRBSI 低減効果)に基づき，1\% CHG-EtOH は 10\% PVP-I よりも皮膚消 毒薬としての特性に優れることが確認された。これらの知見より，1\%CHG-EtOH は臨床におい てカテーテル関連血流感染の発生リスクを低減することが期待される.

Key words : $1 \mathrm{w} / \mathrm{v} \%$ クロルヘキシジン $(\mathrm{CHG})$ エタノール $(1 \% \mathrm{CHG}-\mathrm{EtOH})$, カテーテル関連血流 感染(CRBSI), CDC ガイドライン, 皮膚累積刺激性

はじめに

皮膚消毒はカテーテル関連血流感染を制御する手段と して重要である1,2). 米国においては毎年 170 万の医療 関連感染が発生し, 約 99,000 人の死亡が報告される. そのうち約 31,000 人の死亡原因は血流感染(BSI)によ ると推定される3)。また，BSIによる患者は平均 7〜21

1)吉田製薬株式会社研究開発本部・微生物研究部, 2) 東京医療 保健大学/大学院
日と入院期間が長期化する傾向が見られ，それに伴い患 者への負担や病院コストの増大などが問題視されてい $ろ^{4)}$.

カテーテル関連血流感染発生原因とそのメカニズムに 関しては, 幾つかの要因の関与が挙げられる. 特に, カ テーテル挿入部位の微生物污染により, 皮膚常在菌が血 管内へ持ち込まれた結果として血流感染が引き起こされ るリスクが高い5)。また，カテーテル関連血流感染 (CRBSI)の 60\%は皮膚常在菌により引き起こされ, 起 
因菌となる皮膚菌叢の $80 \%$ は表皮角層表層の上部 5 層 に常在することが報告されていることから ${ }^{6)}$, カテーテ ル挿入部位の消毒は, 感染対策のターゲットとして重要 である。

CRBSI 起因菌のうち重要な菌種としては, コアグ ラーゼ陰性ブドウ球菌 (Coagulase-negative staphylococci：CNS）やMRSA を含む黄色ブドウ球菌 (Staphylococcus aureus), 腸球菌 (enterococci)などが挙 げられる。ささらに，グラム陰性菌の大腸菌 (Escherichia coli)や緑膿菌 (Pseudomonas aeruginosa), 真菌のカンジ ダ (Candida albicans) も検出される7).

さらに, カテーテルの種類とそのデバイスから検出さ れるCRBSI 起因菌との関係を調べた Maki らの研究に よると, カテーテル種類により原因菌が異なることが知 られる. 短期留置用のカテーテルでは, 皮膚由来の CNS, S. aureus などの菌種が最も多く検出され, 長期 留置用のカテーテルでは, グラム院性桿菌, 次いで, CNS の順で検出割合が高い傾向を示した。つまり，こ れらの起因菌によりカテーテルハブやルーメン(内腔)が 污染された結果, CRBSI が引き起こされたとの報告内 容である ${ }^{8,9)}$.

次に, CRBSI 予防策としての皮膚消毒の役割につい て注目して見ると, カテーテル挿入部位は体外と血管を 直接結びつける接点であり, 皮膚常在菌が血管内に直接 持ち込まれるリスクの大きい部位である.したがって, カテーテル挿入部位周辺の菌数を低レベルに維持するこ とは，血管内へ感染起因菌が侵入するリスクを低減する ことに繋がることから, 皮膚消毒薬の使用は CRBSI 予 防のための効果的な手段といえる.

カテーテル関連血流感染 (CRBSI), 特に中心静脈カ テーテル関連血流感染 (CLABSI) 予防のための戦略とし て，エビデンスが明確な幾つかの手技を組合せ，断片的 ではなく総合的な感染対策を行なうことにより最大の効 果を期待する包括的な対策 (バンドルアプローチ)が Pronovost らにより提案されている10,11). バンドルの重 要 5 項目〔1) カテーテル挿入前の手指衛生, 2) 高度無 菌のマキシマル・バリアプリコーション，3)挿入部の クロルヘキシジンでの皮膚消毒, 4) 挿入部位の選択 (大 腿静脈の回避)，5)不必要なカテーテルの抜去」のう ち, カテーテル挿入部をクロルヘキシジン $(\mathrm{CHG})$ で皮 膚消毒する手技は, カテーテル関連血流感染予防の上 で, 重要な役割を果たすとされる.これまで, 皮膚消毒 薬として 10\%ポビドンヨード液 $(10 \% \mathrm{PVP}-\mathrm{I})$ が広く使 用されてきた。しかし, 米国 CDCが「血管カテーテル 関連感染予防のためのガイドライン 2011」を公表し 「中心静脈カテーテルや末梢動脈カテーテル挿入前抢よ びドレッシング交換時にはクロルヘキシジン $(\mathrm{CHG})$ 濃 度が $0.5 \%$ を超える $(>0.5 \%)$ アルコール製剤で皮膚消毒
すること」（カテゴリー1A)を推奨した ${ }^{12)}$. 英米などの 諸外国に打いては，すでに皮膚消毒薬として，主に CHG を $2 \%$ 含有するアルコール製剤が医療現場で使用 されているが，薬事上，わが国で皮膚に適用できる $\mathrm{CHG}$ の上限濃度は $1 \%$ である。これら状況下，日本国 内の医療現場においても，血管内留置カテーテル扦入部 位の皮膚消毒薬として，1\% CHG を含有するエタノー ル製剂 (1\% CHG-EtOH)の使用例が増加傾向にある.

これら現状を踏まえ, in vivo での薬効評価（消毒 7 日 後の持続効果) 抢よび実使用上に打方安全性評価(皮膚 累積刺激性試験)により $1 \% \mathrm{CHG}-\mathrm{EtOH}$ の製剂特性を科 学的に調べた.

\section{材料と方法}

\section{1. 試験製剂}

$0.5 \mathrm{w} / \mathrm{v} \% \mathrm{CHG}$ エタノール $(0.5 \% \mathrm{CHG}-\mathrm{EtOH})[0.5 \%$ ヘキザック®アルコール液, 吉田製薬秼], $1 \mathrm{w} / \mathrm{v} \%$

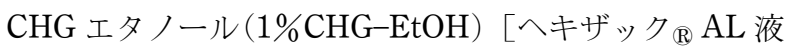
$1 \%$, 吉田製薬秼], $2 \mathrm{w} / \mathrm{v} \% \mathrm{CHG}$ イソプロパノール (2\% CHG-IPA) [ChloraPrep ${ }^{\circledR}$, CareFusion] および 10 $\mathrm{w} / \mathrm{v} \%$ ポビドンヨード液 $(10 \% \mathrm{PVP}-\mathrm{I})$ [ポピヨドン®液 $10 \%$ ，吉田製薬侏]

\section{In vivo 薬効評価}

米国における皮膚消毒薬のための標準試験法 ASTM Standard Method E1173-0913) に従い，注射部位，力 テーテル挿入部位，手術部位での消毒場面を想定し米国 人健常ボランティアを組込み, 米国において試験を行っ た。評価部位として鼠径部, 腹部, 前腕部に着目し, 薬 剂で皮膚を消毒した後, カップスクラブ法でサンプリン グを行い 0.5\% CHG-EtOH, 1\% CHG-EtOH, 2\% CHGIPA および $10 \% \mathrm{PVP}-\mathrm{I}$ の薬効について消毒前に対する 消毒後の菌数対数減少 $\left(\log _{10}\right.$ reduction) で比較検討した.

本検討は，米国の試験施設において開催された倫理委 員会での IRB 承認を得た上で実施した (Gallatin Institutional Review Board [GIRB] 承認: 2011 年 5 月 24 日).

まず，募集された健常人ボランティアの皮膚の常在菌 数 (ベースライン菌数)を測定し, 対象部位毎に定められ た菌数の基準 (前腕部: $\geqq 2.0 \log _{10} \mathrm{CFU} / \mathrm{cm}^{2}$, 腹部 : $\geqq 2.6 \log _{10} \mathrm{CFU} / \mathrm{cm}^{2}$, 鼠径部: $\geqq 4.5 \log _{10} \mathrm{CFU} / \mathrm{cm}^{2}$ ) を満たした被験者を選定し試験に組み込んだ。試験にエ ントリーした被験者は, 皮膚のベースライン菌数を安定 化・維持する目的で, 抗菌剂入りの石けん, シャンプー などの使用を 14 日間制限し，試験開始 72 時間前には 入浴, シャワーも禁止した.

皮膚からのサンプル採取のタイミングは，消毒前ベー スライン測定時, 消毒直後 (30 秒後), 72 時間後および 7 日後とした。採取したサンプル液は, 中和剤で不活化 処理を行った後，それぞれ培地に 3 連で塗沫した。薬 
効比較は, 消毒前に対する消毒後の菌数対数減少 $\left(\log _{10}\right.$ reduction)を指標に行った.

\section{3. 試験製剂での皮膚消毒およびサンプル採取}

$10 \mathrm{~mL}$ の試験製剂は, 滅菌ガーゼ (USP type VII gauze)に含浸し各部位に塗布した(腹部, 前腕部 : 30 秒 間の消毒後, 30 分間乾燥. 鼠径部 : 2 分間の消毒後, 30 分間乾燥). さらに, カップスクラブ法の手順に従 い, 滅菌済みのステンレス製シリンダー $\left(3.46 \mathrm{~cm}^{2}\right)$ を皮 膚に当て, シリンダー内に中和剤含有のサンプリング夜 $3.0 \mathrm{~mL}$ を添加後, 滅菌済みのラバーポリスマンで 1 分 間擋拌・抽出操作を行い皮膚から回收液を採取した．同 様の手順でサンプリング操作を繰返し行った後, 回収液 を混合した. 採取したサンプルは菌数測定のため培地に 塗沫し培養に供した。なお，消毒 72 時間後および 7 日 後の評価を行う被験者の消毒部位は, 污染を防ぐため, 滅菌ガーゼおよびカテーテルドレッシング材で被覆しサ ンプリング時間まで留置した。

\section{4. 中和剂}

$1 \mathrm{~L}$ の滅菌水に $\mathrm{Na}_{2} \mathrm{HPO}_{4} 10.1 \mathrm{~g}, \mathrm{KH}_{2} \mathrm{PO}_{4} 0.4 \mathrm{~g}$, Triton $\mathrm{X}-1001 \mathrm{~mL}$, Lecithin $11.67 \mathrm{~g}$, Polysorbate 80 $100 \mathrm{~mL}, \mathrm{Na}_{2} \mathrm{~S}_{2} \mathrm{O}_{3} \cdot 5 \mathrm{H}_{2} \mathrm{O} 5 \mathrm{~g}$ および Sodium naphthalate $\left(\mathrm{Tamol}^{\mathrm{TM}} \mathrm{SN}\right) 10.0 \mathrm{~g}$ を含む中和剂を調製し滅菌後使用 した．試験前に，ASTM Standard Method E1054-0814) に従い, あらかじめ中和バリデーションを行い各試験製 剂の中和性能を確認した.

\section{5. 培養および菌数測定}

カップスクラブ法で回収した中和処理後のサンプル液 $1.0 \mathrm{~mL}$ は希釈後, 中和剂含有の Trypticase Soy Agar (TSA) 培地 3 枚に塗沫し $30 \pm 2^{\circ} \mathrm{C}, 72$ 時間培養を行っ た.さらに, 生育出現したコロニー数を測定し, シャー レ 3 枚の菌数の平均值から $\log _{10} \mathrm{CFU} / \mathrm{cm}^{2}$ 值を算出 し, 薬効の指標である $\log _{10}$ reduction $\left[\log _{10} \mathrm{CFU}\right.$ (消毒 前べースライン菌数 $)-\log _{10} \mathrm{CFU}$ (消毒後菌数)]に変換 した後，製剤間で比較した。

\section{6. 皮膚累積刺激性試験 (RIPT)}

実使用上の安全性に関しては，ヒト皮膚累積刺激性を 指標に評価を行った。試験製剤として，1\% CHG-EtOH， 2\%CHG-IPA，10\%PVP-I および Positive Control(陽 性対照)として $0.1 \%$ Sodium lauryl sulfate を用い, 23 人の被験者を試験に組み込み, 21 日間連続で皮膚に薬 剂を接触した後に生じる皮膚反応を Repeat Insult Patch Test (RIPT)の手順に従いパッチ法で評価し数值 化した．つまり，0.02 mL の薬液を Finn Chambers ${ }^{\circledR}$ on Scanpor patches (Smart Practice Finland $\mathrm{Oy}^{\circledR}$, Finland) に含浸し調製した後，背中皮膚に貼付した．薬剤は適用 後 24 時間経過した時点で除去し, 皮膚反応のスコアー を FDA/CDER のガイダンスに定められる基準15)に従 い判定した(表 1). その後, 同様の操作を 21 日間連続
表 1 皮膚刺激性の判定基準

\begin{tabular}{c|l}
\hline 評点 & \multicolumn{1}{|c}{ 皮 膚 反 応 } \\
\hline 0 & 刺激なし \\
\hline 1 & わずかな紅斑, かろうじて可視化 \\
\hline 2 & 明らかな紅斑, わずかな浮腫, わずかな丘疹反応 \\
\hline $3^{*}$ & 紅斑および丘疹 \\
\hline $4^{*}$ & 明らかな浮腫 \\
\hline $5^{*}$ & 紅斑, 浮腫および丘疹 \\
\hline $6^{\dagger}$ & 小水疱性の発疹 \\
\hline $7^{\dagger}$ & 試験部位を越えた強い反応 \\
\hline
\end{tabular}

* 試験製剤の適用中止の基準

†副作用により試験中止の基準

で実施し最終判定日は 22 日目とした。ささらに，累積刺 激性の判定には 22 日間の各スコアの積算值を用いた.

\section{7. 統計解析}

微生物学的薬効評価 $\left(\log _{10}\right.$ reduction) および皮膚累積 刺激性試験(RIPT スコア)の結果に関する統計解析は, 分散分析 (Analysis of variance [ANOVA])を行った後, Scheffé 法を用い多重比較し有意水準 5\%で検定を行っ た。

\section{結果}

\section{In vivo 薬効評価}

評価対象の各部位のベースライン菌数 $\left(\log _{10} \mathrm{CFU} /\right.$ $\left.\mathrm{cm}^{2}\right)$ は, 前腕部 : $3.13 \pm 0.47$, 腹部 : $3.31 \pm 0.19$, 鼠径 部 : $5.57 \pm 0.61$ であった. 消毒後の微生物学的な薬効 は $\log _{10}$ reduction 值で示した（図1，2）。消毒 7 日後， $1 \% \mathrm{CHG}-\mathrm{EtOH}$ では菌数増殖を抑制する傾向が観察さ れたが，10\% PVP-I では菌の再増殖が顕著となった。 腹部での消毒後の持続効果に注目すると, 消毒 7 日後 に颃いて，1\%CHG-EtOH の薬効 $\left(2.45 \pm 0.99 \log _{10}\right.$ reduction)は, $10 \% \mathrm{PVP}-\mathrm{I}\left(0.90 \pm 1.39 \mathrm{Log}_{10}\right.$ reduction $)$ と比べ統計学的に有意であることが明らかとなった $(\mathrm{p}$ $=0.020)$. また，前腕抢よび鼠径部に㧍いても， $1 \%$

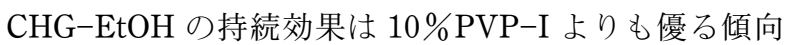
を示した.さらに, 消毒直後ならびに消毒 7 日後とも に全ての部位に抢いて $1 \% \mathrm{CHG}-\mathrm{EtOH}$ の薬効は $2 \%$ CHG-IPA と同等レベルであることが確認された $(\mathrm{p}>$ $0.05)$.

\section{2. 皮膚累積刺激性}

実使用上の皮膚への安全性を評価する目的で，RIPT の手順に従いパッチ法を用い，ヒトでの皮膚刺激性試験 を実施した。その結果，1\% CHG-EtOH の累積刺激性 評点 (282) は $2 \% \mathrm{CHG}-\mathrm{IPA}(715), 10 \% \mathrm{PVP}-\mathrm{I}(837)$ より も低い傾向を示した $(\mathrm{p}>0.05)$ (表 2). 


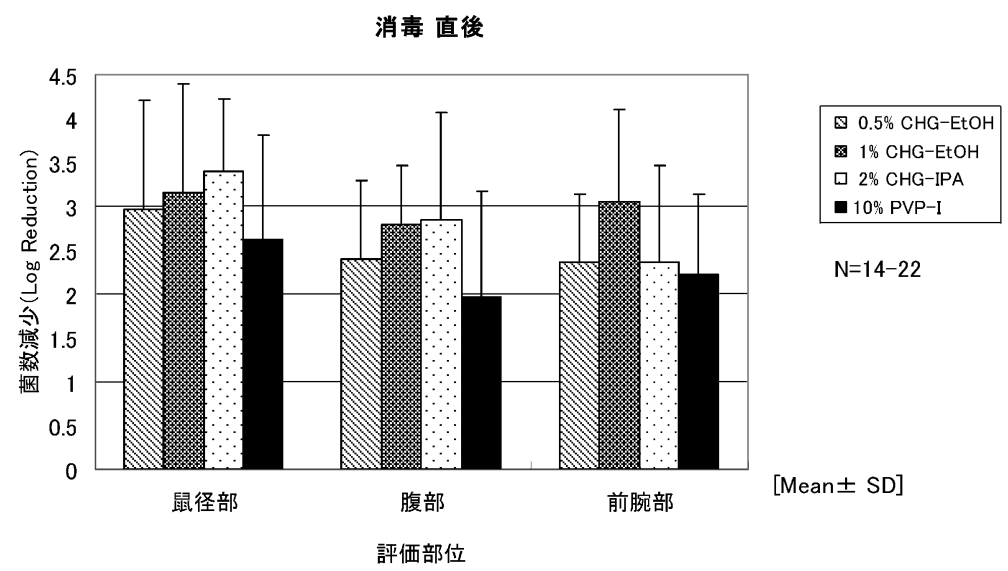

図 1 消毒直後における薬効

0.5\%CHG-EtOH : $0.5 \mathrm{w} / \mathrm{v} \%$ クロルヘキシジンエタノール

1\%CHG-EtOH : $1 \mathrm{w} / \mathrm{v} \%$ クロルヘキシジンエタノール

$2 \% \mathrm{CHG}-\mathrm{IPA}: 2 \mathrm{w} / \mathrm{v} \%$ クルヘキシジンイソプロパノール

$10 \% \mathrm{PVP}-\mathrm{I}: 10 \mathrm{w} / \mathrm{v} \%$ ポビドンヨード液

消毒 7日後

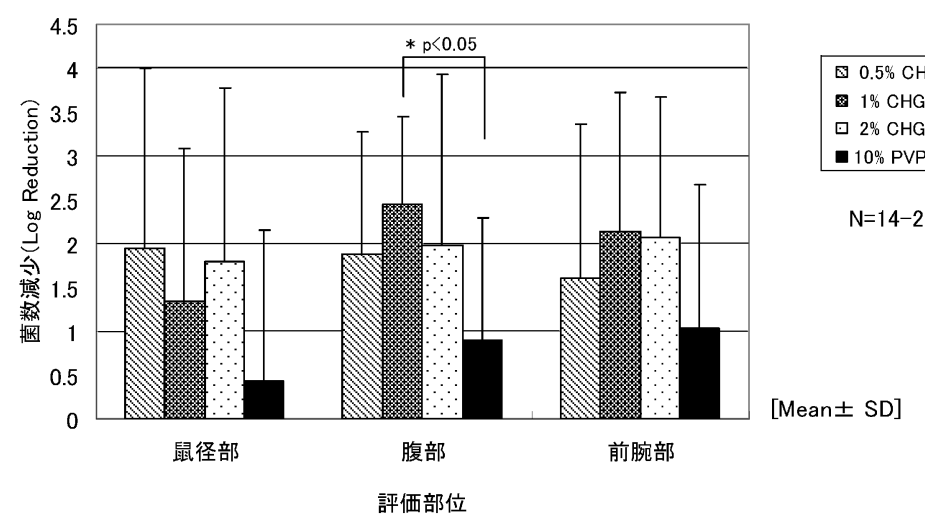

図 2 消毒 7 日後における薬効 (持続効果)

$0.5 \% \mathrm{CHG}-\mathrm{EtOH}: 0.5 \mathrm{w} / \mathrm{v} \%$ \%ロルヘキシジンエタノール

1\%CHG-EtOH : $1 \mathrm{w} / \mathrm{v} \%$ クルルヘキシジンエタノール

$2 \% \mathrm{CHG}-\mathrm{IPA}: 2 \mathrm{w} / \mathrm{v} \%$ ロルヘキシジンイソプロパノール

$10 \% \mathrm{PVP}-\mathrm{I}: 10 \mathrm{w} / \mathrm{v} \%$ ポビドンヨード液

表 2 皮膚刺激性試験(21日連続 RIPT 評価)

\begin{tabular}{|c|c|c|c|c|}
\hline \multirow{2}{*}{$\begin{array}{c}\text { 刺激性 } \\
\text { 評点 } \\
(N=21)\end{array}$} & \multicolumn{4}{|c|}{ 試 験 薬 剂 } \\
\hline & $\begin{array}{c}1 \% \mathrm{CHG}^{-} \\
\text {EtOH }\end{array}$ & $\begin{array}{l}2 \% \mathrm{CHG}^{-} \\
\text {IPA }\end{array}$ & 10\%PVP-I & $\begin{array}{l}\text { Positive } \\
\text { Control }\end{array}$ \\
\hline 平均 $\pm S D$ & $11.76 \pm 11.98$ & $29.86 \pm 18.57$ & $37.33 \pm 20.87$ & $12.43 \pm 9.52$ \\
\hline $\begin{array}{c}\text { 累積 } \\
\text { 刺激性 }\end{array}$ & 282 & 715 & 837 & 272 \\
\hline
\end{tabular}

* Positive Control; $0.1 \%$ sodium lauryl sulfate

$1 \% \mathrm{CHG}-\mathrm{EtOH}: 1 \mathrm{w} / \mathrm{v} \%$ クロルヘキシジンエタノール

2\%CHG-IPA：2 w/v\%クロルヘキシジンイソプロパノール

$10 \%$ PVP-I : $10 \mathrm{w} / \mathrm{V} \%$ ポビドンヨード液
考察

カテーテル関連血流感染 (CRBSI)のリスクを下げる 手段として，確実に皮膚消毒を行い，カテーテル插入部 位周辺の微生物数を減少させておくことが肝要である. 特に, カテーテルが長期間留置された場合, 消毒薬の薬 効が皮膚上で持続することが重要である，なぜなら，力 テーテル留置期間の長期化に伴いカテーテルへの菌の定 着率が, 留置後 4 日目以降有意に増加し, CRBSI 発生 のリスクは, 留置後 5〜 7 日目にかけてさらに高まるこ とを Mermel らが報告しているからである16).

Bart らの研究によると, CRBSI 起因菌の多くは皮膚 常在菌由来であり, 挿入部への菌定着と CRBSI 発生率 との間に相関性があることが報告されている，従って， 
皮膚上のカテーテル挿入部位に抢ける菌定着或いは菌数 推移のモニタリングがカテーテル感染のリスクを推測す るための重要な指標となりうる17)。しかし，実際にカ テーテルが長期間留置された状況或いはドレッシング交 換の場面を想定し, 微生物学的見地から実験モデルで消 毒後の皮膚菌数を測定し, 実際に皮膚消毒薬の持続効果 を検証した事例は少ない。

これら状況を踏をえ, 我々はカテーテル挿入後, 時間 経過した場面をシミュレートした評価モデルを構築し， 鼠径部, 腹部, 前腕を対象に, 健常人ボランティアを試 験に組反込み, 米国標準法 ASTM standard E1173 の プロトコールに従い， $0.5 \% \mathrm{CHG}-\mathrm{EtOH}, 1 \% \mathrm{CHG}-$ $\mathrm{EtOH}, 2 \% \mathrm{CHG}-\mathrm{IPA}$ 抢よび 10\% PVP-I の持続効果 (消 毒 7 日後)を比較した.

本論文で示した微生物学的な薬効面からの比較におい て， $0.5 \% \mathrm{CHG}-\mathrm{EtOH}$ および $2 \% \mathrm{CHG}-\mathrm{IPA}$ の持続効果 は 3 部位全てにおいて $10 \% \mathrm{PVP}-\mathrm{I}$ よりも優れる傾向を 示したが, 統計学的な有意差は観察さ机なかった. しか しながら, 消毒 7 日後の腹部に㧍ける $1 \% \mathrm{CHG}-\mathrm{EtOH}$ の持続効果は, $10 \% \mathrm{PVP}-\mathrm{I}$ と比較し統計学的に有意で あることが明らかとなった。また，1\%CHG-EtOH の 薬効は $2 \% \mathrm{CHG}-\mathrm{IPA}$ と同等レベルであることも確認さ れた.

$0.5 \% \mathrm{CHG}-\mathrm{EtOH}$ と $1 \% \mathrm{CHG}-\mathrm{EtOH}$ の微生物学的薬 効にも統計的な有意差は見られなかった. カテーテル関


「カテーテル挿入部位に適用される皮膚消毒薬の $\mathrm{CHG}$ 濃度は $0.5 \%$ を超える $(>0.5 \%)$ アルコール製剂であるこ と」が推奨されているが, その背景の 1 つに, 中心静 脈カテーテルへの菌定着または CRBSI に着目した Humar らの臨床研究において，0.5\%CHG アルコールは 10\% PVP-I と比較して差が観察されなかったこと ${ }^{18)}$ が あげられる。つまり， $0.5 \%$ CHG-EtOH が $10 \% \mathrm{PVP}-\mathrm{I}$ に比べ CRBSI を有意に低下させたことを明確に示す研 究例はなく, CRBSI 低減策として $0.5 \% \mathrm{CHG}-\mathrm{EtOH}$ を 採用することでは有効性が不十分であることから， $\lceil\mathrm{CHG}$ 濃度が 0.5\%を超える $(>0.5 \%)$ アルコール製郕」 を推奨する，というスタンスをCDCガイドライン著者 (O’ Grady ら) は主張している $\left.{ }^{19}\right)$. これらも勘案すると, $0.5 \% \mathrm{CHG}-\mathrm{EtOH}$ よりも $1 \% \mathrm{CHG}-\mathrm{EtOH}$ の方が皮膚消 毒薬として有用とする考え方は矛盾しないと判断する.

また，皮膚累積刺激性試験を実施し製剂間で比較した 結果, $1 \% \mathrm{CHG}-\mathrm{EtOH} の$ 累積刺激性は, $2 \% \mathrm{CHG}-\mathrm{IPA}$ 或いは $10 \% \mathrm{PVP}-\mathrm{I}$ よりも低刺激の傾向を示し, 局所刺 激性の観点から皮膚適用の安全性が確認された20).

$\mathrm{CHG}$ 製剂の臨床適用に目を向けると, 海外において は, カテーテル挿入部位の皮膚消毒薬として $\mathrm{CHG}$ 含有 製剤の臨床的な有用性について報告された事例が多数存
在する18,21 30). 以下，日本国内に打ける臨床的エビデ ンスの報告例を紹介した．まず，カテーテル関連血流感 染発生のリスクが $1 \%$ CHG-EtOH と 10\%PVP-I との間 で比較評価された国内初の事例報告として, 谷村らの研 究が知られる ${ }^{31}$. つまり, 対象としたカテーテル挿入 患者 85 名の皮膚表面から採取された培養陽性率は, 1\% CHG-EtOH 群 10.3\% (10/97 件) に対し 10\%PVP-I 群 22.6\% (19/84 件)であり，1\%CHG-EtOH 群で有意 に低功た $(\mathrm{p}=0.024$, カイ 2 乗検定)。また，血流感 染の発生は, $1 \% \mathrm{CHG}-\mathrm{EtOH}$ 群 $2.3 \%$ (1/43 件) に対し $10 \% \mathrm{PVP}-\mathrm{I}$ 群 20.0\% (10/50 件)であった. 以上より, $1 \%$ CHG-EtOH を用いた皮膚消毒は，10\% PVP-I より もカテーテル挿入部位の微生物数を減少させる効果が高 く, 血流感染発生のリスクを低減させる傾向が確認され たことを結論とした。さらに二例目として，CLABSI 予防策として中心静脈カテーテル $(\mathrm{CVC})$ 挿入部位の皮 膚消毒薬として, 従来の $0.5 \% \mathrm{CHG}-\mathrm{EtOH}$ 或いは $10 \%$ PVP-I を $1 \%$ CHG-EtOH に全面切り替えした前後（以 下, 前, 後と略)に打ける CLABSI 発生率を比較した, 長尾らの研究報告が挙げられる322。つまり, CLABSI 発生率/1,000 device-day を比較した結果, 血液・循環 器内科病棟 (前 2.3 , 後 2.7 ) に抢いて有意差はなかっ た. 呼吸器 - 消化器内科病棟 (前 3.3 , 後 2.1) では, 減 少傾向を示したが有意差は観察されなかったＩCU（前 3.9 , 後 0)ではゼロを達成したが統計学的に有意ではな かった。外科病棟 (前 7.1, 後 0) では大幅に CLABSI が 低減し有意差を認めた $(\mathrm{p}=0.011)$. 以上より, CVC 挿 入部位の皮膚消毒薬として $1 \% \mathrm{CHG}-\mathrm{EtOH}$ を導入した 結果, 呼吸器 - 消化器内科, ICU 抢よび外科病棟に打 いてCLABSI の低減効果が確認された。外科病棟では $1 \% \mathrm{CHG}-\mathrm{EtOH}$ 導入に加え, スタッフ教育や継続的介 入を行うことでケアを改善したことも CLABSI 発生の 低減に寄与したことを筆者らは結論した。

現段階で国内に打ける $1 \% \mathrm{CHG}-\mathrm{EtOH}$ の臨床的エビ デンスは，海外での $2 \% \mathrm{CHG}$ 含有製剂を用いた臨床事 例に比べ, 症例数, 施設数共に少ないが, これら研究報 告において CRBSI 低減策としての有用性が示されたこ とから, 今後 $1 \% \mathrm{CHG}-\mathrm{EtOH}$ を適用した臨床研究に弾 みがつくことが期待される，また，本研究の結果を踏ま え, 我が国に扔いても, 大規模な臨床試験を実施しエビ デンスデータの蓄積が必要と考えられる.

日本国内では薬事上, $\mathrm{CHG}$ 適用上限濃度が $1 \%$ であ る事情も考慮し, 先に紹介した薬効の持続効果抢よび皮 膚適用時の安全性などの特徵, さらに, 国内の臨床的工 ビデンスから総合的に判断し，カテーテル挿入部位の皮 膚消毒薬として $1 \% \mathrm{CHG}-\mathrm{EtOH}$ を選択することは妥当 であると考察された。

以上，本研究を通じて得られた情報をもとに，1\% 
CHG-EtOH を CDC ガイドライン推奨の皮膚消毒薬と して国内で使用することは, 本剂の有する消毒効果の持 続性などの特性から，長期間血管内に留置されたカテー テル挿入部位での CRBSI リスク低減効果が期待できる.

利益相反について : 本研究のうち米国での試験は吉田製薬侏か らの委託研究費により実施された. 西原 豊, 梶浦 工, 横田 勝弘は吉田製薬秼の社員である. 前者を除く共同著者に関する 利益相反はない。

\section{文献}

1) Garibaldi RA, Skolnick D, Lerer T, Poirot A, Graham $\mathrm{J}$, Krisuinas $\mathrm{E}$, et al.: The impact of preoperative skin disinfection on preventing intraoperative wound contamination. Infect Control Hosp Epidemiol 1988; 9: 109-13.

2) Crosby CT, Mares AK: Skin antisepsis: past, present and future. J Vasc Access Devices 2001; 6: 26-31.

3) Centers for Disease Control and Prevention: Guidelines for the prevention of intravascular catheter-related infections. CDC 2011; 8-9. (http://stacks.cdc.gov/view/ $\operatorname{cdc} / 5916 /)$

4) Kirkland KB, Briggs JP, Trivette SL, Wilkinson WE,Sexton DJ: The impact of surgical site infections in the 1990s: attributable mortality, excess length of hospitalization, and extra costs. Infect Control Hosp Epidemiol 1999; 20: 725-30.

5) Crnich CJ, Maki DG: The promise of novel technology for the prevention of intravascular device-related bloodstream infection. I. Pathogenesis and short-term devices. Clin Infec Dis 2002; 34: 1232-42.

6) Brown E, Wenzel RP, Hendley JO: Exploration of the microbial anatomy of normal human skin by using plasmid profiles of coagulase-negative staphylococci: search for the reservoir of resident skin flora. J Infect Dis 1989; 160 (4): 644-650.

7) O'Grady NP, Alexander M, Dellinger EP, Gerberding JL, Heard SO, Maki DG, et al.: Guidelines for the prevention of intravascular catheter-related infections. Clin Infect Dis 2002; 35: 1281-307.

8) Maki DG: Vina del Mar Infection Control Conference, June 20, 2011.

9) Maki DG, Kluger DM , Crnich CJ: The risk of bloodstream infection in adults with different intravascular devices: A systematic review of 200 published prospective studies. Mayo Clin Proc 2006; 81: 1159-71.

10) Pronovost P, Needham D, Berenholtz S, Sinopoli D, Chu $\mathrm{H}$, Cosgrove $\mathrm{S}$, et al.: An intervention to decrease catheter-related bloodstream infections in the ICU. N Engl J Med 2006; 355: 2725-32.

11) Pronovost $P$ : Interventions to decrease catheter-related bloodstream infections in the ICU: the Keystone Intensive Care Unit Project. Am J Infect Control 2008; 36 (10): S171. e1-5.

12) Centers for Disease Control and Prevention: Guidelines for the prevention of intravascular catheter-related infections. CDC 2011; 13-21. (http://stacks.cdc.gov/ view/cdc/5916/)

13) ASTM standard E1173-09. Standard test method for evaluation of preoperative, precatheterization, or prein- jection skin preparations. West Conshohocken $[\mathrm{PA}]$ : ASTM International; 2009.

14) ASTM standard E1054-08. Standard test method for evaluation of preoperative,precatheterization, or preinjection skin preparations. West Conshohocken $[\mathrm{PA}]$ : ASTM International; 2008.

15) FDA/CDER Guidance for Industry, Skin Irritation and Senstization Testing of Generic Transdermal Drug Products, December 1999.

16) Mermel LA, Maki DG: Infectious complications of Swan-Ganz pulmonary artery catheters. Pathogenesis, epidemiology, prevention, and management. Am J Respir Crit Care Med 1994; 149: 1020-36.

17) Rijnders BJ,Van Wijngaerden E,Peetermans WE: Catheter-Tip Colonization as a Surrogate End Point in Clinical Studies on Catheter-Related Bloodstream Infection: How Strong Is the Evidence? Clin Infect Dis 2002; 35: 1053-8.

18) Humar A, Ostromecki A, Direnfeld J, Marshall JC, Lazar N, Houston PC, et al.: Prospective randomized trial of $10 \%$ povidone-iodine versus $0.5 \%$ tincture of chlorhexidine as cutaneous antisepsis for prevention of central venous catheter infection. Clin Infect Dis 2000; 31: 1001-7.

19) Renes SH, Pompe JC, Renes MH: Prevention of intravascular central venous catheter-related infections: $0.5 \%$ concentration of chlorhexidine preparation with alcohol for skin preparation and femoral vein for renal replacement therapy. Clin Infect Dis 2011; 53: 745-56, Reply to authors by O' Grady SH et al.: 746-8.

20) Nishihara $Y$, Kajiura $T$, Yokota $K$, Kobayashi $H$, Okubo T: Evaluation with a focus on both the antimicrobial efficacy and cumulative skin irritation potential of chlorhexidine gluconate alcohol-containing preoperative skin preparations. Am J Infect Control 2012; 40: 973-8.

21) Vallés J, Fernández I, Alcaraz D, Chacón E, Cazorla A, Canals M, et al.: Prospective randomized trial of 3 antiseptic solutions for prevention of catheter colonization in an intensive care unit for adult patients. Infect Control Hosp Epidemiol 2008; 29: 847-53.

22) Reichel M, Heisig P, Kohlmann T, Kampf G: Alcohols for skin antisepsis at clinically relevant skin sites. Antimicrob Agents Chemother 2009; 53: 4778-82.

23) Hibbard JS, Mulberry GK, Brady AR: A clinical study comparing the skin antisepsis and safety of ChloraPrep, $70 \%$ isopropyl alcohol, and 2\% aqueous chlorhexidine. J Infus Nurs 2002; 25: 244-9.

24) Leyden JJ, McGinley KJ, Foglia AN, Wahrman JE, Gropper CN, Vowels BR: A new method for in vivo evaluation of antimicrobial agents by translocation of complex dense populations of cutaneous bacteria. Skin Pharmacol 1996; 9: 60-8.

25) Maki DG, Ringer M, Alvarado CJ: Prospective randomized trial of povidone-iodine, alcohol, and chlorhexidine for prevention of infection associated with central venous and arterial catheters. Lancet 1991; 338: 33943.

26) Chaiyakunapruk N, Veenstra DL, Lipsky BA, Saint S: Chlorhexidine compared with povidone-iodine solution for vascular catheter-site care: a meta-analysis. Ann Intern Med 2002; 136: 792-801.

27) Lilly HA, Lowbury EJ, Wilkins MD: Detergents compared with each other and with antiseptics as skin "de- 
germing” agents. J Hyg (Lond) 1979; 82: 89-93.

28) Pottinger JM, Starks SE, Steelman VM: Skin preparation. Perioper Nurs Clin 2006; 1: 203-10.

29) Maki DG, Knasinski V, Narans LL,Gordon BJ: A randomized trial of a novel 1\% chlorhexidine $75 \%$ alcohol tincture vs. $10 \%$ povidone-iodine for cutaneous disinfection with vascular catheters. Toronto: Annual Scientific Meeting of the Society for Healthcare Epidemiology of America (SHEA); 2001.

30) Weber DJ, Rutala WA: Central line-associated bloodstream infections: prevention and management. Infect Dis Clin North Am 2011; 25: 77-102.
31）谷村久美，大久保憲：血管内留置カテーテル挿入部位 の皮膚消毒に関する検討. 環境感染誌 2010; 25 (5): 281-5.

32）長尾博美，荒木雅史，滝本秀隆，木村圭吾，鈴木 勉：新たな皮膚消毒剂と継続的教育による中心静脈力 テーテル関連血流感染低減の評価。香川労㷋病誌 2011; 17: 121-4.

〔連絡先 : ₹350-1316 埼玉県狭山市南入曽 951 吉田製薬株式会社研究開発本部・微生物研究部 西原 豊

E-mail: nishihara_yutaka@yoshida-pharm.co.jp]

\title{
Use of $1 w / v \%$ Chlorhexidine Gluconate in Alcohol Formulation for Reducing The Risk of Catheter-Related Bloodstream Infection
}

\author{
Yutaka NishinarA ${ }^{1,2)}$, Takumi KaJIURA ${ }^{1,2)}$, Katsuhiro YoKota ${ }^{11}$, \\ Hiroyoshi KobaYashi ${ }^{2)}$, Erisa Sugawara ${ }^{2)}$ and Takashi OKUBO $^{2)}$ \\ 1) Yoshida Pharmaceutical Co., Ltd., Microbiological Research Dept., Research \& Development Div. \\ 2) Tokyo Healthcare University Postgraduate School
}

\begin{abstract}
In Japan, 10\% povidone-iodine solution (10\% PVP-I) is commonly used for precatheter preparation. Recently, the CDC 2011 guidelines for the prevention of intravascular catheter-related infections clearly recommended skin preparation with alcohol containing $>0.5 \% \mathrm{CHG}$ as a means of preventing catheter-related bloodstream infection (CRBSI). Since then, CHG-alcohol products have been more widely used. Japanese pharmaceutical regulations limit CHG content in skin antiseptics to a maximum of $1 \%$. Under these circumstances, we present some properties of $1 \mathrm{w} / \mathrm{v} \%$ chlorhexidine gluconate in ethanol formulation $(1 \% \mathrm{CHG}-\mathrm{EtOH})$. We found that $1 \% \mathrm{CHG}-\mathrm{EtOH}$ had comprehensive advantages of antimicrobial efficacy (long-lasting effects), safety in use (low potential for skin irritation) and clinical efficacy (reduced CRBSI in clinical studies). Considering these findings, $1 \% \mathrm{CHG}-\mathrm{EtOH}$ is expected to perform well at the catheter insertion site to reduce the risk of CRBSI.
\end{abstract}

Key words : $1 \mathrm{w} / \mathrm{v} \%$ chlorhexidine gluconate in ethanol formulation (1\% CHG-EtOH), catheterrelated bloodstream infection (CRBSI), CDC guidelines, cumulative skin 